\title{
Detection of DNA adducts derived from the reactive metabolite of furan, cis-2-butene-1,4-dial
}

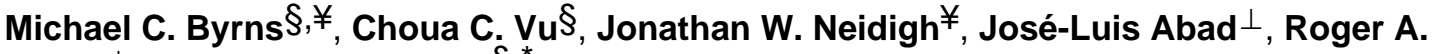 \\ Jones $^{\perp}$, and Lisa A. Peterson $\S,{ }^{*}$ \\ $\S$ Division of Environmental Health and Cancer Center, University of Minnesota, Minneapolis MN, 55455 \\ $¥$ Department of Biochemistry and Microbiology Loma Linda University Medical School Loma Linda, CA \\ 92350
}

$\perp$ Department of Chemistry and Chemical Biology, Rutgers University, Piscataway, NJ 08854

\begin{abstract}
Furan is a toxic and carcinogenic compound used in industry and commonly found in the environment. The mechanism of furan's carcinogenesis is not well understood, and may involve both genotoxic and nongenotoxic pathways. Furan undergoes oxidation by cytochrome P450 to cis-5-2butene-1,4-dial, which is thought to mediate furan's toxic effects. Consistently, cis-5-2-butene-1,4dial readily reacts with glutathione, amino acids, and nucleosides. To determine the importance of DNA alkylation in furan-induced carcinogenesis, we developed an assay for the detection of cis-2butene-1,4-dial-derived DNA adducts. DNA samples were treated with $O$-benzyl-hydroxylamine, which reacts with the aldehyde functionality of the DNA adducts. Enzyme hydrolysates of these samples were then analyzed by capillary electrospray tandem mass spectrometry (LC/ESI-MS/MS) with selected reaction monitoring. The dCyd and dAdo adducts were detected in digests of DNA treated with nanomolar concentrations of $c$ is-2-butene-1,4-dial. In addition, these adducts were present in DNA isolated from Ames Assay strain TA104 treated with mutagenic concentrations of cis-2-butene-1,4-dial. These data support the hypothesis that cis-butene-1,4-dial is a genotoxic metabolite of furan. This method will allow us to explore the role of these adducts in furan-induced carcinogenesis.
\end{abstract}

\section{Keywords \\ DNA adducts; furan; cis-2-butene-1,4-dial; derivatization; $O$-benzylhydroxyl-amine; capillary LC- MS}

\section{Introduction}

Furan is an important environmental compound found in food, cigarette smoke, and air pollution $(1,2)$. Furan is used extensively in industry, both as a solvent and as an intermediate in the synthesis of several important compounds (3). The National Toxicology Program (NTP) reported extensive liver and kidney damage and an increased rate of hepatocellular carcinomas in rats and mice treated with furan (3). Based on these observations, they concluded that furan is "reasonably anticipated to be a human carcinogen" (4).

\footnotetext{
*To whom requests for reprints should be addressed at The Cancer Center, University of Minnesota, Mayo Mail Code 806, 420 Delaware St. S.E., Minneapolis, MN 55455. Phone: 612-626-0164; fax: 612-626-5135; email: peter431@umn.edu.

${ }^{¥}$ Current address: Michael Byrns, Department of Pharmacology, University of Pennsylvania, 135 John Morgan Bldg., 3620 Hamilton

Walk, Philadelphia, PA 19104.
} 
The toxicological activity of furan requires P450-mediated activation (Scheme 1) (5-7). Furan's toxicity in hepatocytes is inhibited by the P450 inhibitor, imidazole, and induced by acetone pretreatment (7). Consistent with the involvement of a reactive metabolite in the toxicity, the levels of in vitro microsomal protein binding of furan were enhanced in microsomes from rats pretreated with $\mathrm{P} 450$ inducers (6). The postulated reactive intermediate is the $\alpha, \beta$-unsaturated dialdehyde, cis-2-butene-1,4-dial, which has been detected in microsomal incubations of furan $(8-10)$ and reacts with amino acids and glutathione $(9,10)$.

The underlying mechanism of furan-induced carcinogenesis is not well understood. Several studies have suggested a potential genotoxic mechanism. cis-2-Butene-1,4-dial is mutagenic in the Ames assay (11). Furan was also clastogenic in Chinese hamster ovary cells (12), and cis-2-butene-1,4-dial has been shown to induce DNA single-strand breaks and cross-links in these cells (13). Tumors from mice treated with furan have different ras mutations than spontaneous tumors in untreated animals $(14,15)$. However, other studies have suggested that furan is not genotoxic and that another mechanism, such as toxicity and compensatory cell proliferation, is responsible for furan-induced carcinogenesis. Furan did not induce reversions in S. typhimurium TA100, TA1535, TA1537, and TA98 strains in the presence or absence of an S9 activating system (16). There was also no initiation of DNA repair in the livers of rats and mice treated with furan (17). However, furan induces a significant increase in cell proliferation in both rats and mice $(17,18)$.

The lack of consistency in the mechanistic data for furan-induced carcinogenesis indicates the need for further research. Cellular reaction products such as DNA adducts can provide insights into the mechanisms of carcinogenesis and toxicity. Previous research has shown that the microsomal metabolite of furan cis-2-butene-1,4-dial reacts with dCyd to form an oxadiazabicyclooctaimine adduct (1, Scheme 2) (19) and with dAdo and dGuo to form initial ethano adducts ( $\mathbf{2}$ and $\mathbf{3}$, respectively) (20) that rearrange to form etheno-acetaldehyde adducts (4 and 5, respectively) (21). The current study describes the development of a sensitive liquid chromatography electrospray tandem mass spectrometry (LC/ESI-MS/MS) assay for the detection of cis-2-butene-1,4-dial-derived adducts in DNA and its application to study their formation in DNA from cis-2-butene-1,4-dial-treated bacteria.

\section{Experimental Procedures}

\section{Caution}

cis-2-Butene-1,4-dial is toxic and mutagenic, and should be handled with proper safety equipment and precautions.

\section{Materials}

dCyd, dAdo, dGuo and $O$-benzylhydroxylamine were purchased from Sigma (St. Louis, MO). Acid phosphatase, DNase II, phosphodiesterase II, RNase A and T, and proteinase $\mathrm{K}$ were purchased from 89MP Biomedical (Irvine, CA). ${ }^{13} \mathrm{C}_{4}$-Furan was synthesized using a published method (22). cis-2-Butene-1,4-dial and ${ }^{13} \mathrm{C}_{4}$-cw-2-butene-1,4-dial were prepared by oxidizing either unlabeled or ${ }^{13} \mathrm{C}_{4}$-furan with dimethyldioxirane (23). Solution concentrations were determined as previously reported (11). ${ }^{15} \mathrm{~N}_{3}$-dCyd, ${ }^{15} \mathrm{~N}_{3}$-dAdo and ${ }^{15} \mathrm{~N}_{3}$-dGuo were synthesized as previously described (24-26).

\section{Instrumental Analysis}

HPLC analyses were performed with a Shimadzu HPLC system linked to a dual channel Shimadzu UV detector, employing one of two methods. For Method 1, a Prodigy C18 column $(5 \mu, 150 \times 4.6 \mathrm{~mm}$; Phenomenex, Torrence, $\mathrm{CA})$ was eluted with a $40 \mathrm{~min}$ linear gradient from 
0 to $80 \%$ acetonitrile in water. Method 2 employed a 25 min linear gradient from 0 to $25 \%$ acetonitrile in water.

${ }^{1} \mathrm{H}$ NMR analyses were performed with a Varian VI-500 MHz NMR and are reported in ppm relative to an external standard.

\section{Characterization of the $\mathbf{O}$-Benzyloxime Derivatives of the Nucleoside Adducts}

cis-2-Butene-14-dial $(0.06 \mathrm{mmol})$ was reacted with dCyd, dAdo, or dGuo $(0.09 \mathrm{mmol})$ in 50 $\mathrm{mM}$ sodium phosphate, $\mathrm{pH} 7$, for $24 \mathrm{~h}$ (dCyd and dAdo) or $6 \mathrm{~h}$ (dGuo) at $37^{\circ} \mathrm{C}$ (total volume: $5 \mathrm{~mL})$. Then, $O$-benzylhydroxylamine $(\sim 0.3 \mathrm{mmol})$ in $100 \mathrm{mM}$ sodium phosphate, $\mathrm{pH} 7$ (1 $\mathrm{mL}$ ) was added and the solutions were incubated at $37{ }^{\circ} \mathrm{C}$ for $1 \mathrm{~h}$ (dCyd and dAdo) or $24 \mathrm{~h}$ (dGuo). Acetone $(100 \mu \mathrm{L})$ was added to remove excess $O$-benzylhydroxylamine. The resulting derivatized ethano-dCyd (6), etheno-dAdo (7), and etheno-dGuo (8) adducts were then collected from HPLC (Method 1) and concentrated under reduced pressure. The samples were desalted via solid phase extraction with Strata-X $6 \mathrm{~mL} / 500 \mathrm{mg}$ cartridges (Phenomenex, Torrence CA). After the sample was loaded onto the cartridge $(4 \mathrm{~mL})$, the cartridge was washed once with $17.5 \% \mathrm{MeOH}$ in $\mathrm{H}_{2} \mathrm{O}(6 \mathrm{~mL})$ and twice with $100 \% \mathrm{MeOH}(6 \mathrm{~mL})$. The first methanol fraction was then concentrated to dryness under reduced pressure.

Efforts to weigh the resulting products were unsuccessful due to their hydroscopic nature. Instead, quantitative ${ }^{1} \mathrm{H}$ NMR analysis was performed on aliquots of the purified adducts $(\sim 1$ $\mathrm{mg}$ ), using 2,2-dimethyl-2-silapentane-5-sulfonate (DSS) as an internal standard (7.57 $\mathrm{mM}$ for 6, $0.473 \mathrm{mM}$ for 7 , or $1.20 \mathrm{mM}$ for 8$)$ in $\mathrm{D}_{2} \mathrm{O}(600 \mu \mathrm{L})$. The concentration of the adduct solutions were determined by integrating ${ }^{1} \mathrm{H}$ signals of the adducts relative to those of DSS. This analysis indicated that the dAdo and dCyd adducts were $>99 \%$ pure and the dGuo adducts were $>95 \%$ pure. The resulting solutions were then diluted 100 fold in $50 \mathrm{mM}$ potassium phosphate, $\mathrm{pH}$ 7, and the UV absorbance at 281, 279, or $284 \mathrm{~nm}$ was measured for $\mathbf{6}, \mathbf{7}$, and $\mathbf{8}$, respectively, against a blank containing the appropriate concentration of DSS in $\mathrm{D}_{2} \mathrm{O}$. The extinction coefficient for each adduct was determined with Beer's law using the UV absorbance and the experimentally determined concentration.

\section{7-Hydroxy-8-(acetaldehyde-O-benzyloxime)-3,N $\mathrm{N}^{4}$-ethano-2'-deoxycytidine (6)} $-{ }^{1} \mathrm{H}$ NMR $\left(\mathrm{D}_{2} \mathrm{O}, \mathrm{ppm}\right)$ major isomer $1-\delta 7.48(\mathrm{~d}, J=8.3 \mathrm{~Hz}, 1 \mathrm{H}, \mathrm{H}-6), 7.39-7.15(\mathrm{~m}, 5 \mathrm{H}$, $\left.\mathrm{C}_{6} \mathrm{H}_{5}\right) ; 6.74(\mathrm{~m}, 1 \mathrm{H}, \mathrm{H}-10) ; 6.03-5.96\left(\mathrm{~m}, 1 \mathrm{H}, \mathrm{H}-1^{\prime}\right) ; 5.85(\mathrm{~d}, J=8.0 \mathrm{~Hz}, 1 \mathrm{H}, \mathrm{H}-5) ; 5.22(\mathrm{~m}$, 1H, H-7); 4.93-4.81 (m, 2H, CH 2 ); 4.25-4.19 (m, 2H, H3', H-8); 3.85-3.80 (m, 1H, H-4'); 3.62-3.54 (m, 2H, H-5'); 2.99-2.50 (m, 2H, H-9); 2.15-1.88 (m, 2H, H-2'). Major isomer 2 - $\delta$ 7.42 (m, 1H, H-6), 7.41 (m, 1H, H-10); 7.39-7.15 (m, 5H, $\left.\mathrm{C}_{6} \mathrm{H}_{5}\right)$; 6.03-5.96 (m, 1H, H-1'); 5.75 (dd, $J=8.8,4.0 \mathrm{~Hz}, 1 \mathrm{H}, \mathrm{H}-5) ; 5.17$ (m, $1 \mathrm{H}, \mathrm{H}-7) ; 4.93-4.81\left(\mathrm{~m}, 2 \mathrm{H}, \mathrm{CH}_{2}\right) ; 4.25-4.19$ (m, 2H, H-3', H-8); 3.85-3.80 (m, 1H, H-4 '); 3.62-3.54 (m, 2H, H-5'); 2.99-2.50 (m, 2H, H-9); 2.15-1.88 (m, 2H, H-2'). MS m/z (relative intensity) 417 (M+1, 100). MS/MS $m / z$ (relative intensity) $301(\mathrm{M}+1-2$-deoxyribose, 100). Extinction coefficient $(281 \mathrm{~nm})=$ $8.6 \times 10 \mathrm{M}^{-1} \mathrm{~cm}^{-1}$

11-(Acetaldehyde-O-benzyloxime)-1, $\mathbf{N}^{6}$ etheno-2'-deoxyadenosine (7)- ${ }^{1} \mathrm{H}$ NMR $\left(\mathrm{D}_{2} \mathrm{O}, \mathrm{ppm}\right)$ major isomer (trans) - $\delta 8.49(\mathrm{~s}, 1 \mathrm{H}, \mathrm{H}-2) ; 8.33(\mathrm{~s}, 1 \mathrm{H}, \mathrm{H}-8) ; 7.60(\mathrm{t}, J=4.6 \mathrm{~Hz}$, $1 \mathrm{H}, \mathrm{H}-13) ; 7.26$ (s, $1 \mathrm{H}, \mathrm{H}-10) ; 7.06-6.81\left(\mathrm{~m}, 5 \mathrm{H}, \mathrm{C}_{6} \mathrm{H}_{5}\right) ; 6.38\left(\mathrm{dd}, J=6.8 \mathrm{~Hz}, 1 \mathrm{H}, \mathrm{H}-1^{\prime}\right)$; $\left(\mathrm{H}-3^{\prime}\right.$ and oxime $\mathrm{CH}_{2}$ obscured by water); $4.07(\mathrm{~m}, 1 \mathrm{H}, \mathrm{H}-4$ '); 3.83 (d, J=4.6 Hz, 2H, H-12); 3.74-3.65 (m, 2H, H-5'); 2.79 (m, 1H, H-2'); $2.51\left(\mathrm{~m}, 1 \mathrm{H}, \mathrm{H}-2^{\prime}\right)$; minor isomer (cis) - $\delta 8.65$ (s, 1H, H-2); 8.30 (s, 1H, H-8); 7.60 (t, $J=4.6 \mathrm{~Hz}, 1 \mathrm{H}, \mathrm{H}-13) ; 7.26$ (s, $1 \mathrm{H}, \mathrm{H}-10) ; 7.06-6.81$ $\left(\mathrm{m}, 5 \mathrm{H}, \mathrm{C}_{6} \mathrm{H}_{5}\right) ; 6.45$ (dd, $\left.J=6.8 \mathrm{~Hz}, 1 \mathrm{H}, \mathrm{H}^{\prime} \mathbf{1}^{\prime}\right)$; ( $3^{\prime}$ and oxime $\mathrm{CH}_{2}$ obscured by water); 4.07 (m, 1H, H-4'); 3.89 (d, J=4.6 Hz, 2H, H-12); 3.74-3.65 (m, 2H, H-5'); 2.79 (m, 1H, H-2'); 2.51 
(m, 1H, H-2'). MS m/z (relative intensity) 423 (M+1, 100). MS/MS $m / z$ (relative intensity) 307 $\left(\mathrm{M}+1-2^{\prime}\right.$-deoxyribose, 100). Extinction coefficient $(279 \mathrm{~nm})=5.9 \times 10^{3} \mathrm{M}^{-1} \mathrm{~cm}^{-1}$.

11-(Acetaldehyde-O-benzyloxime)-1, $\mathrm{N}^{2}$-etheno-2'-deoxyguanosine (8)- ${ }^{1} \mathrm{H}$ NMR $\left(\mathrm{D}_{2} \mathrm{O}, \mathrm{ppm}\right) \delta 7.92(\mathrm{~s}, 1 \mathrm{H}, \mathrm{H}-8) ; 7.59(\mathrm{t}, J=4.2 \mathrm{~Hz}, 1 \mathrm{H}, \mathrm{H}-13) ; 6.94-6.76(\mathrm{~m}, 5 \mathrm{H}$, $\left.\mathrm{C}_{6} \mathrm{H}_{5}\right) ; 6.82(\mathrm{~s}, 1 \mathrm{H}, \mathrm{H}-10) ; 6.25\left(\mathrm{dd}, J=7.1 \mathrm{~Hz}, 1 \mathrm{H}, \mathrm{H}-1^{\prime}\right) ;\left(3^{\prime}\right.$ and oxime $\mathrm{CH}_{2}$ obscured by water); $4.02\left(\mathrm{~m}, 1 \mathrm{H}, \mathrm{H}-\mathrm{C} 4{ }^{\prime}\right) ; 3.78\left(\mathrm{~d}, J=3.9 \mathrm{~Hz}, 2 \mathrm{H}, \mathrm{C} 12-\mathrm{H}_{2}\right) ; 3.66-3.62\left(\mathrm{~m}, 2 \mathrm{H}, \mathrm{H}-5^{\prime}\right) ; 2.76$ (m, 1H, H-2'); 2.42 (m, 1H, H-2 '). MS m/z (relative intensity) 439 (M+1, 100). MS/MS m/z (relative intensity) $323\left(\mathrm{M}+1-2^{\prime}\right.$-deoxyribose, 100). Extinction coefficient $(284 \mathrm{~nm})=1.57 \times$ $10^{4} \mathrm{M}^{-1} \mathrm{~cm}^{-1}$

\section{Synthesis of Internal Standards}

${ }^{13} \mathrm{C}_{4}$ - cis-2-Butene-1,4-dial (2 mM) was reacted with $1 \mathrm{mM}{ }^{15} \mathrm{~N}_{3}$-dCyd, ${ }^{15} \mathrm{~N}_{3}$-dAdo, or ${ }^{15} \mathrm{~N}_{3^{-}}$ dGuo in $10 \mathrm{mM}$ sodium phosphate for $24 \mathrm{~h}, 10 \mathrm{~h}$, or $6 \mathrm{~h}$ respectively at $37^{\circ} \mathrm{C}$ (total volume 1 $\mathrm{mL}$ ). The primary products were isolated by HPLC (Method 2) and concentrated to $750 \mu \mathrm{L}$ under reduced pressure. $O$-Benzylhydroxylamine $(40 \mathrm{mM})$ in $100 \mathrm{mM}$ sodium phosphate $\mathrm{pH}$ $7(250 \mu \mathrm{L})$ was added and the solution incubated for $1 \mathrm{~h}\left({ }^{15} \mathrm{~N}_{3}\right.$-dCyd $)$ or $24 \mathrm{~h}\left({ }^{15} \mathrm{~N}_{3}\right.$-dAdo and ${ }^{15} \mathrm{~N}_{3}$-dGuo $)$ at $37^{\circ} \mathrm{C}$. Acetone $(50 \mu \mathrm{L})$ was then added and the resulting peaks were isolated by HPLC (Method 1) and concentrated under reduced pressure. The concentrations of the solutions were determined by UV analysis. Their structures were confirmed by MS analysis.

${ }^{15} \mathrm{~N}_{3},{ }^{13} \mathrm{C}_{4}-6 \mathrm{MS} \mathrm{m} / \mathrm{z}$ (relative intensity) 424 (M+1, 100). MS/MS $\mathrm{m} / \mathrm{z}$ (relative intensity) 308 $(\mathrm{M}+1-2$ '-deoxyribose, 100$)$.

${ }^{15} \mathrm{~N}_{3},{ }^{13} \mathrm{C}_{4}-\mathbf{7} \mathbf{M S} \mathrm{m} / \mathrm{z}$ (relative intensity) $430(\mathbf{M}+1,100)$. MS/MS $\mathrm{m} / \mathrm{z}$ (relative intensity) 314 $\left(\mathrm{M}+1-2^{\prime}\right.$-deoxyribose, 100).

${ }^{15} \mathrm{~N}_{3},{ }^{13} \mathrm{C}_{4}-\mathbf{8} \mathbf{~ M S ~} \mathrm{m} / \mathrm{z}$ (relative intensity) 446 (M+1 100). MS/MS $\mathrm{m} / \mathrm{z}$ (relative intensity) 330 $(\mathrm{M}+1-2$ '-deoxyribose, 100$)$.

\section{Preparation of cis-2-butene-1,4-dial-treated Calf Thymus DNA}

DNA $(0.3 \mathrm{mg})$ and cis-2-butene-1,4-dial $(0,0.08,0.4,2,10$, or $50 \mu \mathrm{M})$ were incubated in 50 $\mathrm{mM}$ potassium phosphate, $\mathrm{pH} 7$, at $37^{\circ} \mathrm{C}$ (total volume $500 \mu \mathrm{L}$ ). After $6 \mathrm{~h}$, DNA was precipitated with ethanol, washed with $70 \%$ ethanol to remove excess cis-2-butene-1,4-dial and dried under $\mathrm{N}_{2}$. The samples were then analyzed for DNA adduct formation using the method described below.

\section{Treatment of S. typhimurium TA104 Bacteria with cis-2-Butene-1,4-dial}

Cultures of S. typhimurium TA104 were grown up overnight in oxoid \#2 nutrient broth and the concentration was checked by its optical density at $650 \mathrm{~nm}$ (1.7 O.D.). For each sample, $100 \mathrm{~mL}$ of the culture were centrifuged at $4,000 \times \mathrm{g}$ for $10 \mathrm{~min}$. The resultant pellet was suspended in $200 \mathrm{mM}$ sodium phosphate buffer, $\mathrm{pH} 7.4$, containing $0,1.42,2.14$, or $2.86 \mathrm{mM}$ cis-2-butene-1,4-dial (total volume $7 \mathrm{~mL}$ ). After $30 \mathrm{~min}$ at $30^{\circ} \mathrm{C}$, the bacteria were then pelleted at $4000 \times \mathrm{g}$ for $10 \mathrm{~min}$. They were washed with $7 \mathrm{~mL}$ sodium phosphate buffer to remove any remaining cis-2-butene-1,4-dial and collected by centrifugation $(4000 \times \mathrm{g}$ for $10 \mathrm{~min})$. DNA was isolated with a modification of the method of Wang et al (27). The bacterial pellet was suspended in a lysis buffer containing $1 \% \mathrm{w} / \mathrm{v}$ SDS, $5 \mathrm{mM}$ EDTA, $10 \mathrm{mM}$ sodium phosphate, $\mathrm{pH} 7.5$ (total volume $8 \mathrm{~mL}$ ). RNase A was added to a final concentration of $0.2 \mathrm{mg} / \mathrm{mL}$, and the solution was incubated for $10 \mathrm{~min}$ at $37^{\circ} \mathrm{C}$. Then proteinase $\mathrm{K}(1 \mathrm{mg} / \mathrm{mL})$ was added and the solution incubated for $1 \mathrm{~h}$ at $37^{\circ} \mathrm{C}$. DNA was precipitated with sodium iodide and isopropanol. It was redissolved in $50 \mathrm{mM}$ potassium phosphate, $\mathrm{pH} 7(5 \mathrm{~mL})$, and extracted with an equal volume of 24:1 chloroform/isoamyl alcohol. DNA was precipitated with ethanol, 
washed with $70 \%$ ethanol, dried under $\mathrm{N}_{2}$ and analyzed for cis-2-butene-1,4-dial-derived DNA adducts with the protocol described below.

\section{Assay for cis-2-butene-1,4-dial-derived DNA adducts}

DNA $(300 \mu \mathrm{g})$ was dissolved in $50 \mathrm{mM}$ potassium phosphate, $\mathrm{pH} 8$, and $2.88 \mu \mathrm{mol} O$ benzylhydroxylamine was added (total volume $572(\mu \mathrm{L})$. Reactions were performed in triplicate. Following $18 \mathrm{~h}$ incubation at $37^{\circ} \mathrm{C}$, the samples were precipitated with ethanol at ambient temperature and washed twice with $70 \%$ ethanol. This DNA was then subjected to enzymatic hydrolysis, employing the method reported by Dennehy and Loeppky $(28,29)$. Digestions were performed with $0.3 \mathrm{mg} / \mathrm{mL}$ DNA in $83 \mathrm{mM}$ ammonium acetate, $\mathrm{pH} 5$, containing $8.3 \mathrm{mM}$ magnesium sulfate, $20 \mathrm{mM}$ ammonium chloride, $660 \mathrm{U} / \mathrm{mL}$ deoxyribonuclease II, and $0.49 \mathrm{U} / \mathrm{mL}$ phosphodiesterase II.After a 20 min incubation at $37^{\circ}$ $\mathrm{C}$, wheat germ acid phosphatase type $\mathrm{I}(1.8 \mathrm{U} / \mathrm{mL})$ and the internal standards $(90$ fmol ${ }^{13} \mathrm{C}_{4},{ }^{15} \mathrm{~N}_{3}-6,60 \mathrm{fmol}{ }^{13} \mathrm{C}_{4},{ }^{15} \mathrm{~N}_{3}-7$, and $~ 90 \mathrm{fmol}{ }^{13} \mathrm{C}_{4},{ }^{15} \mathrm{~N}_{3}-8$ ) were added to each sample. These solutions were then incubated for an additional $24 \mathrm{~h}$. Then, each sample was filtered through a nylon membrane syringe filter $(0.45 \mu \mathrm{m}$ pore, $0.4 \mathrm{~mm}$ diameter, Millex-HN; Millipore Corporation, Billerica, MA). A portion was retained for dGuo analysis $(50 \mu \mathrm{L})$. The DNA adducts were isolated by solid phase extraction (Strata-X $30 \mathrm{mg}$ cartridges, Phenomenex. Torrence CA) with sequential water, $20 \%$ methanol, and $100 \%$ methanol washes ( $1 \mathrm{~mL}$ each). The methanol wash, which contained the adducts, was concentrated to approximately $25 \mu \mathrm{L}$ under reduced pressure for analysis by capillary LC-MS.

Capillary LC-MS analyses were performed with an Agilent capillary LC system linked to a ThermoFinnigan Quantum triple quadrapole mass spectrometer with an electrospray ionization source in positive mode. The capillary temperature was set to $265^{\circ} \mathrm{C}$, spray voltage to $4 \mathrm{kV}$, and sheath gas pressure to 35 . Direct injection of standards was accomplished with the standards dissolved in $50 \%$ acetonitrile in $10 \mathrm{mM}$ ammonium acetate injected onto the source by a syringe pump with a flow rate of $15 \mu \mathrm{L} / \mathrm{min}$. Standards were then analyzed in full scan mode followed by MS/MS analysis of the predominant ions with the collision energy set to $15 \mathrm{~V}$. LC-MS/MS selected reaction monitoring was performed with a scan time of $0.2 \mathrm{sec}$ and an isolation width of $0.2 \mathrm{~m} / \mathrm{z}$ under 1 of 2 conditions: the fragmentations resulting from loss of the 2'-deoxyribose $\left[417 \rightarrow 301(\mathbf{6}), 424 \rightarrow 308\left({ }^{15} \mathrm{~N}_{3},{ }^{13} \mathrm{C}_{4}-\mathbf{6}\right), 423 \rightarrow 307(7), 430 \rightarrow 314\right.$ $\left({ }^{15} \mathrm{~N}_{3},{ }^{13} \mathrm{C}_{4}-7\right), 439 \rightarrow 323(8)$, and $\left.446 \rightarrow 330\left({ }^{15} \mathrm{~N}_{3},{ }^{13} \mathrm{C}_{4}-8\right)\right]$ were monitored with the collision energy set at $15 \mathrm{~V}$, and the fragmentations resulting from the sequential loss of 2'-deoxyribose, water and the $O$-benzyloxyl group from the dCyd adducts $[417 \rightarrow 176(6), 424 \rightarrow 183$ $\left({ }^{15} \mathrm{~N}_{3},{ }^{13} \mathrm{C}_{4}-\mathbf{6}\right)$ and the sequential loss of 2 '-deoxyribose followed by formaldehyde- $O$-benzyloxime from the dAdo adducts $\left[423 \rightarrow 173(7)\right.$, and $\left.430 \rightarrow 180\left({ }^{15} \mathrm{~N}_{3},{ }^{13} \mathrm{C}_{4}-7\right)\right]$ were monitored with the collision energy set at $25 \mathrm{~V}$. Liquid chromatography was performed with a ZORBAX SB-C18 capillary column $(5 \mu \mathrm{m}, 150 \times 0.5 \mathrm{~mm}$; Agilent Technologies, Palo Alto, CA) eluted at $15 \mu \mathrm{L} / \mathrm{min}$ with a gradient of 20 to $50 \%$ acetonitrile in $10 \mathrm{mM}$ ammonium acetate over 10 min followed by an $80 \%$ acetonitrile wash for $5 \mathrm{~min}$.

Quantification with the ${ }^{15} \mathrm{~N}_{3},{ }^{13} \mathrm{C}_{4}-6$ and ${ }^{15} \mathrm{~N}_{3},{ }^{13} \mathrm{C}_{4}-7$ internal standards was validated by preparing solutions of a single concentration of the ${ }^{15} \mathrm{~N}_{3},{ }^{13} \mathrm{C}_{4}$-labeled standard $(1.5 \mathrm{fmol} / \mu \mathrm{L}$ for $7,2.25 \mathrm{fmol} / \mu \mathrm{L}$ for 6$)$ with varying concentrations of unlabeled standards $(0.03,0.15,0.75$, 3.75 , and $18.75 \mathrm{fmol} / \mu \mathrm{L}$ for each). These solutions were then analyzed by capillary LC-MS with selective reaction monitoring as described above. The relationship between the predicted and observed ratios of labeled to unlabeled compound was plotted and fit to a linear regression. Because of the presence of a coeluting peak with the same mass as ${ }^{13} \mathrm{C}_{4},{ }^{15} \mathrm{~N}_{3}-6$ in the bacterial DNA hydrolysates, the adducts were quantified with the collision energy set to $25 \mathrm{~V}$ ( $417 \rightarrow 176$ for $\mathbf{6}, 423 \rightarrow 173$ for 7 ). 
The concentration of DNA in each sample was determined by measuring the concentration of dGuo and dAdo in each DNA hydrolysate. This was achieved through HPLC with UV detection by comparison of the dGuo or dAdo peak areas to standard curves (30). Adduct levels were then normalized to the total number of DNA bases or unmodified parent nucleoside present in the sample. We assumed that the quantity of dCyd equaled that of dGuo.

\section{Results \\ Development of LC/ESI-MS/MS method for the detection of cis-2-butene-1,4-dial-derived DNA adducts}

To detect cis-2-butene-1,4-dial-derived adducts in DNA, we proposed to develop an LC/ESIMS/MS assay similar to those reported for other carcinogen-nucleoside adducts (31). These methods achieve sensitive detection of modified nucleosides by monitoring the characteristic loss of the sugar, $[\mathrm{M}+\mathrm{H}-116]^{+}$. Initial attempts to directly detect cis-2-butene-1,4-dialderived DNA adduct formation via this approach met with little success due to weak ionization of the adducts (data not shown). We suspected that the poor sensitivity resulted from suppression of their ionization by coeluting unmodified nucleosides as well as likely gas-phase reactions involving the aldehydic functionalities of the molecules (32). To improve the separation of cis-2-butene-1,4-dial-derived adducts from the unmodified nucleosides as well as prevent side reactions, we elected to derivatize the aldehyde groups with $O$ -

benzylhydroxylamine. A similar method, utilizing the hydroxylamine aldehyde reactive probe $\mathrm{N}^{\prime}$-aminoxymethyL carbonylhydrazino D-biotin, has been reported for the sensitive detection of the major malondialdehyde-derived deoxyguanosine adduct (33). Our previous observation that methoxyamin2qe reacted readily with the secondary dGuo adducts 5 suggested that all the cis-2-butene-1,4-dial-derived adducts will react with substituted hydroxylamines to form $O$ alkyloxime derivatives (21). These products lack the reactivity of the parent compound. Therefore, we explored the use of $O$-benzylhydroxylamine in the derivatization reactions described below. This particular reagent was chosen for its nonpolar nature, which will allow for greater separation of the adducts from unmodified nucleosides. The overall plan for the detection of cis-2-butene-1,4-dial-derived DNA damage is outlined in Scheme 3.

As predicted, $O$-benzylhydroxylamine reacted with each of the cis-2-butene-11,4-dialnucleoside adducts. Derivatized nucleoside adducts $(\mathbf{6}, \mathbf{7}$, and $\mathbf{8})$ were isolated by HPLC from reaction mixtures containing the primary cis-2-butene-1,4-dial-nucleoside adducts $(\mathbf{1}, \mathbf{2}$, and 3 ) and $O$-benzylhydroxylamine (Scheme 2). Their identities as the $O$-benzyloxime derivatives of the primary dCyd adducts (6) and the secondary dAdo and dGuo adducts ( $\mathbf{7}$ and $\mathbf{8}$ ) were confirmed through MS and ${ }^{1} \mathrm{H}$ NMR analysis. MS analysis of each of the purified compounds indicated the parent ion corresponding to the expected $\mathrm{M}+1$ for each compound $(\mathrm{m} / \mathrm{z} 417$ for $\mathbf{6}, \mathrm{m} / \mathrm{z} 423$ for $\mathbf{7}$, and $\mathrm{m} / \mathrm{z}, 439$ for $\mathbf{8}$ ). ${ }^{1} \mathrm{H}$ NMR analyses of $\mathbf{6}$ and $\mathbf{7}$ indicated the replacement of the aldehyde functionality of the primary dCyd adducts (1) and secondary dAdo adduct (4) with an $O$-benzyloxime group in either a cis or a trans conformation. The ${ }^{1} \mathrm{H}$ NMR of the derivatized dGuo adduct $(\mathbf{8})$ was similar to the previously described ${ }^{1} \mathrm{H}$ NMR of the $O$ methyloxime derivative of the secondary dGuo adduct $(\mathbf{5})$ with the signals corresponding to the benzyl group replacing those of the $\mathrm{CH}_{3}$ group (21).

The mass spectra of 6,7 and 8 all displayed a major fragment ion resulting from the loss of the $2^{\prime}$-deoxyribose group $(\mathbf{6}, 417 \rightarrow 301 ; \mathbf{7}, 423 \rightarrow 307$; and $\mathbf{8}, 439 \rightarrow 323)$ (Scheme 4$)$. When higher collision energies were used ( $25 \mathrm{~V})$, the mass spectra of $\mathbf{6}$ and 7 also displayed further fragmentation of the adduct resulting from the additional loss of water and the benzyloxyl group from $6(417 \rightarrow 176)$ and loss of formaldehyde $O$-benzyl oxime from $7(423 \rightarrow 173)$ (Scheme 4). Both the low energy and high energy transitions were utilized for the quantification and identification of these adducts in DNA exposed to cis-2-butene-1,4-dial. 
Quantification of the adducts by LC/ESI-MS/MS required isotopically labeled standards. Initial studies using standards which were only labeled at the nucleoside indicated that there was a small amount $(\leq 0.1 \%)$ of transfer of unlabeled 2-butene-1,4-dial from the labeled standard to unlabeled nucleosides present in the hydrolysates. This resulted in the artificial formation of unlabelled adducts that complicated the analysis, particularly when higher amounts of standards were employed. To avoid this problem, we prepared dually-labeled standards by reacting ${ }^{13} \mathrm{C}_{4}$-cis-2-butene-1,4-dial with ${ }^{15} \mathrm{~N}_{3}$ cis-dCyd, ${ }^{15} \mathrm{~N}_{3}$-dAdo, or ${ }^{15} \mathrm{~N}_{3}$ dGuo. The resulting cis-2-butene-1,4-dial-derived nucleoside adducts were purified and subsequently reacted with $O$-benzylhydroxylamine to achieve ${ }^{15} \mathrm{~N}_{3},{ }^{13} \mathrm{C}_{4}-\mathbf{6},{ }^{15} \mathrm{~N}_{3},{ }^{13} \mathrm{C}_{4}-7$ and ${ }^{15} \mathrm{~N}_{3},{ }^{13} \mathrm{C}_{4}-8$. The mass spectra of these compounds were shifted by 7 amu from that observed for the unlabeled standards. Any transfer of 2-butene-1,4-dial from the standards to unlabeled nucleosides resulted in the formation of adducts with a 4 amu mass shift, which would not be detected during the analysis.

Standard curves were generated for the derivatized dCyd (6) and dAdo (7) adducts with known ratios of the unlabeled to ${ }^{13} \mathrm{C}_{4},{ }^{15} \mathrm{~N}_{3}$-labeled standards. A plot of the ratio of labeled to unlabeled adducts observed with capillary LC-MS to the expected ratio was linear across the observed range of ratios [6 $(417 \rightarrow 301): y=0.9725 x-0.1406, R^{2}=0.9968 ; 6(417 \rightarrow 176): y=1.0255 x$ $-0.1661, R^{2}=0.9964 ; 7(423 \rightarrow 307): y=1.010 S x-0.0059, R^{2}=1.000 ; 7(423 \rightarrow 173): y=$ $\left.0.9601 \times+0.0264, R^{2}=0.9999\right]$. The limit of detection for both 6 and 7 was $0.24 \mathrm{fmol}$. Standard curves developed with the unlabeled and ${ }^{13} \mathrm{C} 4,{ }^{15} \mathrm{~N} 3$-labeled dGuo adducts $(\mathbf{8})$ varied considerably between preparations, particularly when the standards had been stored at $-120^{\circ}$ $\mathrm{C}$ for greater than a month.

\section{Determination of Adduct Levels in cis-2-Butene-1,4-dial-treated Calf Thymus DNA}

To test our detection method, calf thymus DNA was treated with increasing concentrations of cis-2-butene-1,4-dial for $6 \mathrm{~h}$. We then tried two different protocols for the derivatization reaction. One involved initial enzymatic hydrolysis of the DNA followed by derivatization with $O$-benzylhydroxylamine. The second method reversed these two steps. The first approach was unsuccessful since the excess $O$-benzylhydroxylamine interfered with the subsequent mass spectral analysis and efforts to remove this reagent failed. When the derivatization step was performed first, we were able to remove any unreacted $O$-benzylhydroxylamine by precipitation of the DNA with ethanol prior to the enzymatic hydrolysis step. Experiments were performed by varying the length of time for both the derivatization and enzyme digestion reactions in order to optimize the detection of the three adducts. Levels of adducts $\mathbf{6}$ and $\mathbf{7}$ were maximized when the reaction with $O$-benzyl-hydroxylamine was conducted for $18 \mathrm{~h}$ and the enzymatic digestion preceded for $24 \mathrm{~h}$ (data not shown). Under these conditions, adduct 8 was lost. This adduct was detected when the derivatization was performed for $1 \mathrm{~h}$ with a $4 \mathrm{~h}$ enzyme digestion period. However, the levels of this adduct varied substantially. Because the chemistry of the dGuo adducts prevented reliable analysis of this adduct, we elected to focus on the detection of $\mathbf{6}$ and $\mathbf{7}$.

There was a linear relationship between the formation of the adducts and the concentration of cis-2-butene-1,4-dial (Figure 1). The identity of these adducts was confirmed by monitoring both transitions for each adduct (data not shown). The limits of detection of this assay were less than $0.02 \mathrm{pmol} / \mu \mathrm{mol} \mathrm{dCyd} \mathrm{(}<5$ adduct per $10^{9}$ total bases) for 6 and $0.01 \mathrm{pmol} / \mu \mathrm{mol}$ dAdo for 7 ( $<2.5$ adducts per $10^{9}$ total bases). There was abaseline level of these adducts in control DNA $(\leq 0.01 \mathrm{pmol} / \mu \mathrm{mol}$ unmodified nucleoside), which might be the result of endogenous generation of these adducts. 


\section{Determination of Adduct Levels in DNA from Bacteria Treated with cis-2-Butene-1,4-dial}

We predicted that cis-2-butene-1,4-dial would form adducts in DNA from S. typhimurium TA104 bacteria treated with $c i s$-2-butene-1,4-dial at the concentrations and conditions where mutagenicity was observed (11). To test this hypothesis, adduct levels were determined in DNA isolated from S. typhimurium TA104 bacteria treated with increasing concentrations of cis-2butene-1,4-dial. There was a dose-dependent increase in the levels of both $\mathbf{6}$ and $\mathbf{7}$ in DNA isolated from TA104 bacteria treated with cis-2-butene-1,4-dial (Figure 2), which roughly corresponded to the previously published mutagenicity results (Figure 3) (11). In untreated bacteria, a baseline level of the dAdo adduct $7(\sim 0.01 \mathrm{pmol} / \mu \mathrm{mol} \mathrm{dAdo})$ was detected, but the $\mathrm{dCyd}$ adduct 6 was below the limits of detection $(<0.01 \mathrm{pmol} / \mu \mathrm{mol} \mathrm{dCyd})$.

\section{Discussion}

We have developed a sensitive assay for the detection of DNA adducts derived from cis-2butene-1,4-dial, a reactive metabolite of the environmental carcinogen furan. As predicted based on its reactivity with nucleosides, cis-2-butene-1,4-dial reacts with DNA in vitro to form adducts with dCyd, dAdo, and dGuo in DNA. In addition, the dCyd and dAdo adducts were detected in DNA isolated from S. typhimurium TA104 bacteria treated with mutagenic concentrations of cis-2-butene-1,4-dial.

cis-2-Butene-1,4-dial readily reacts with calf thymus DNA, leading to the formation of DNA adducts that can be sensitively detected through derivatization with $O$-benzylhydroxylamine and subsequent analysis by mass spectrometry. This assay works well for the analysis of the dCyd and secondary dAdo adducts, but not for the detection of adducts formed with dGuo. Our inability to detect the dGuo adduct with this assay is likely the result of its reactive nature. The primary dGuo adducts have the shortest half-life of the initial cis -2-butene-1,4-dialderived adducts, rapidly dehydrating to form the secondary adduct $9(20,21)$. The chemical characterization of 5 was complicated by its reactivity (21); this adduct appeared to form reversible cross-links when concentrated. If 5 exists as a cross-link in DNA, the aldehyde will be resistant to derivatization. The detection of the dGuo adducts is further complicated by the observation that the oxime derivatives of 3 and 5 are still somewhat unstable and subject to further reactions. We are currently investigating strategies to stabilize this adduct.

Although derivatization with $O$-benzylhydroxylamine provides a useful tool for the sensitive detection of DNA adducts formed by cis -2-butene-1,4-dial, there are several limitations to this assay. This assay is at best semi-quantitative since we do not know the yield of the derivatization reaction within DNA. Also, it is likely that the levels of overall dAdo adducts are underestimated because this assay only detects the secondary form of the dAdo adduct (7). Under the conditions used in this study, we were unable to detect derivatized primary adduct, 9 (Scheme 2). This adduct can either undergo dealkylation to yield unmodified dAdo or dehydration to produce 7 (20). The relative contribution of these two pathways to the overall fate of 9 in DNA is not known.

Despite these limitations, this remains a useful assay for the detection of cis -2-butene-1,4dial-derived DNA adducts. Derivatization with $O$-benzylhydroxylamine removes the reactive aldehyde from the adducts, preventing reactions between the adducts and other nucleophiles that would otherwise limit their detection. In addition, the presence of the benzyl group allows for easy separation of the derivatized adducts from the unmodified nucleosides through solid phase extraction, removing another obstacle to the detection of the adducts. Derivatization of the adducts also improves their ionization, enhancing the sensitivity of this assay. Swenberg and coworkers recently reported a similar assay for the dGuo adduct of malondialdehyde, pyrimido $[1,2-a]$ purin-10(3H). Derivatization of this adduct with a hydroxylamine linked to biotin greatly increased its detection by MS (33). 
The observation of DNA adducts in cis -2-butene-1,4-dial-treated bacteria supports the hypothesis that furan is a potentially genotoxic carcinogen (11). The reaction of cis-2butene-1,4-dial with DNA was less efficient in bacteria than with calf thymus DNA in vitro. While differences in reaction conditions (time, temperature) could partially explain this discrepancy, there are many potential competing cellular nucleophiles in the bacterial cell, substantially reducing the amount of externally added cis -2-butene-1,4-dial which reaches DNA.

The correlation between the formation of cis-2-butene-1,4-dial-derived DNA adducts and mutagenicity in the Ames assay suggests that the formation of these adducts is responsible for the mutagenicity of cis -2-butene-1,4-dial. Substitutions at both TA and GC base pairs can lead to phenotype reversion in TA104 $(34,35)$, so any of the described DNA adducts induced by cis -2-butene-1,4-dial could be responsible for its mutagenesis. Future studies will examine the spectrum of mutations induced by cis-2-butene-1,4-dial and the contribution of the various DNA adducts to its mutagenic activity.

The development of an assay for the detection of cis-2-butene-1,4-dial-derived DNA adducts will provide an important tool for the analysis of DNA adduct formation as a result of furan exposure. Their detection in DNA from bacteria treated with cis-2-butene-1,4-dial validates the utility of this derivatization strategy for the analysis of cis-2-butene-1,4-dial-derived DNA damage.

The presence of low levels of 6 and 7 in untreated DNA suggests these adducts could form through an endogenous pathway. Dedon and coworkers have proposed that cis or trans-2butene-1,4-dial formation could result from radical attack to deoxyribose in DNA (36). Therefore, radical reactions with DNA may be responsible for the background levels of these adducts.

In conclusion, the reactive metabolite of furan, cis-2-butene-1,4-dial, reacts with DNA to modify dAdo, dCyd and dGuo. These adducts were observed in DNA isolated from bacteria treated with mutagenic concentrations of cis-2-butene-1,4-dial. These results demonstrate that this reactive metabolite is a genotoxic compound and may be involved in the carcinogenic mechanism of furan.

\section{Supplementary Material}

Refer to Web version on PubMed Central for supplementary material.

\section{Acknowledgements}

Dr. Shana Sturla assisted with the ${ }^{1}$ H NMR studies, and Dr. Peter Villalta and Brock Matter assisted in the MS studies. We thank Bob Carlson for his assistance in the preparation of this manuscript. This work was funded by NIH grant ES-10577. MCB was funded by a Doctoral Dissertation Fellowship from the University of Minnesota Graduate School and NIH Training Grant ES-10956. Supporting information is available: ${ }^{1} \mathrm{H}$ NMR spectra of 6, 7, and 8 with DSS in $\mathrm{D}_{2} \mathrm{O}$

\section{Reference List}

1. Maga J. Furans in foods. Crit Rev Food Sci Nutr 1979;11:355-366.

2. Capurro PU. Effects of exposure to solvents caused by air pollution with special reference to $\mathrm{CCl}_{4}$ and its distribution in air. Clin Toxicol 1973;6:109-124. [PubMed: 4709566]

3. National Toxicology Program. Toxicology and carcinogen sis studies of furan in F344/N rats and B6C $3 F_{1}$ mice vol. NTP Technical Report No. 402. US Department of Health and Human Services, Public Health Service, National Institutes of Health; Research Triangle Park, NC: 1993. 
4. National Toxicology Program. 9th Report on Carcinogens. US Department of Health and Human Services; Washington DC: 2000.

5. Masuda Y, Nakayama N, Yamaguchi A, Murohashi M. The effects of diethyldithiocarbamate and carbon disulfide on acute nephtrotoxicity induced by furan, bromobenzene and cephaloridine in mice. Jap J Pharmacol 1984;34:221-229. [PubMed: 6086999]

6. Parmar D, Burka LT. Studies on the interaction of furan with hepatic cytochrome P-450. J Biochem Toxicol 1993;8:1-9. [PubMed: 8492299]

7. Carfagna MA, Held SD, Kedderis GL. Furan-induced cytolethality in isolated rat hepatocytes: Correspondence with in vivo dosimetry. Toxicol Appl Pharmacol 1993;123:265-273. [PubMed: 8248933]

8. Chen LJ, Hecht SS, Peterson LA. Identification of cis-2-butene-1,4-dial as a microsomal metabolite of furan. Chem Res Toxicol 1995;8:903-906. [PubMed: 8555403]

9. Chen LJ, Hecht SS, Peterson LA. Characterization of amino acid and glutathione adducts of cis -2butene-1,4-dial, a reactive metabolite of furan. Chem Res Toxicol 1997;10:866-874. [PubMed: 9282835]

10. Peterson LA, Cummings ME, Vu CC, Matter BA. Glutathione trapping to measure microsomal oxidation of furan to cis -2-butene-1,4-dial. Drug Metab Dispos 2005;33:1453-1458. [PubMed: 16006568]

11. Peterson LA, Naruko KC, Predecki D. A reactive metabolite of furan, cis -2-butene-1,4-dial, is mutagenic in the Ames assay. Chem Res Toxicol 2000;13:531-534. [PubMed: 10898583]

12. Stich HF, Rosin MP, Wu CH, Powrie WD. Clastogenicity of furans found in food. Cancer Let 1981;13:89-95. [PubMed: 7198003]

13. Marinari UM, Ferro M, Sciaba L, Finollo R, Bassi AM, Brambilla G. DNA-damaging activity of biotic and xenobiotic aldehydes in Chinese hamster ovary cells. Cell Biochem Funct 1984;2:243248. [PubMed: 6518624]

14. Johansson E, Reynolds S, Anderson M, Maronpot R. Frequency of Ha-ras-1 gene mutations inversely correlated with furan dose in mouse liver tumors. Mol Carcinogenesis 1997;18:199-205.

15. Reynolds SH, Stowers SJ, Patterson RM, Maronpot RR, Aaronson SA, Anderson MW. Activated oncogenes in $\mathrm{B}_{6} \mathrm{C}_{3} \mathrm{~F}_{1}$ mouse liver tumors: Implications for risk assessment. Science 1987;237:1309_ 1316. [PubMed: 3629242]

16. Mortelmans K, Haworth S, Lawlor T, Speck W, Tainer B, Zeiger E. Salmonella mutagenicity tests, II. Results from the testing of 270 chemicals. Environmental Mutagenesis 1986;7(suppl):1-119.

17. Wilson DM, Goldsworthy TL, Popp JA, Butterworth BE. Evaluation of genotoxicity, pathological lesions, and cell proliferation in livers of rats and mice treated with furan. Environ Mol Mutagen 1992;19:209-222. [PubMed: 1572344]

18. Fransson-Steen R, Goldsworthy TL, Kedderis GL, Maronpot RR. Furan-induced liver cell proliferation and apoptosis in female $\mathrm{B}_{6} \mathrm{C}_{3} \mathrm{~F}_{1}$ mice. Toxicology 1997;118:195-204. [PubMed: 9129173]

19. Gingipalli L, Dedon PC. Reaction of cis- and trans-2-butene-1,4-dial with 2'-deoxycytidine to form stable oxadiazabicyclooctaimine adducts. J Am Chem Soc 2001;123:2664-2665. [PubMed: 11456937]

20. Byrns MC, Predecki DP, Peterson LA. Characterization of nucleoside adducts of cis-2-butene-1,4dial, a reactive metabolite of furan. Chem Res Toxicol 2002;15:373-379. [PubMed: 11896685]

21. Byrns MC, Vu CC, Peterson LA. The formation of substituted $1, N^{6}$-etheno-2'-deoxyadenosine and $1, N^{2}$-etheno-2'-deoxyguanosine adducts by cis-2-butene-1,4-dial, a reactive metabolite of furan. Chem Res Toxicol 2004;17:1607-1613. [PubMed: 15606136]

22. Vu CC, Peterson LA. Synthesis of $\left[{ }^{13} \mathrm{C}_{4}\right]$ furan. J Label Compounds Radiopharm 2005;48:117-121.

23. Adger BM, Barrett C, Brennan J, McKervey MA, Murray RW. Oxidation of furans with dimethyldioxirane. J Chem Soc, Chem Comm 1991:1553-1554.

24. LaFrancois CJ, Fujimoto J, Sowers LC. Synthesis and characterization of isotopically enriched pyrimidine deoxynucleoside oxidation damage products. Chem Res Toxicol 1998;11:75-83. [PubMed: 9477229]

25. Zhao H, Pagano AR, Wang W, Shallop A, Gaffney B, Jones RA. Use of a ${ }^{13}$ C Atom To Differentiate Two ${ }^{15} \mathrm{~N}$-Labeled Nucleosides. Syntheses of $\left[{ }^{15} \mathrm{NH}_{2}\right]$-Adenosine, $\left[1, \mathrm{NH}_{2^{-}}{ }^{15} \mathrm{~N}_{2}\right]$ - and $\left[2-{ }^{13} \mathrm{C}-1\right.$, 
$\left.\mathrm{NH}_{2^{-}}{ }^{15} \mathrm{~N}_{2}\right]$-Guanosine, and $\left[1,7, \mathrm{NH}_{2^{-}}{ }^{15} \mathrm{~N}_{3}\right]$ - and $\left[2-{ }^{13} \mathrm{C}-1,7, \mathrm{NH}_{2^{-}}{ }^{15} \mathrm{~N}_{3}\right]-2^{\prime}$-Deoxyguanosine. $\mathrm{J}$ Org Chem 1997;62:7832-7835.

26. Pagano AR, Zhao H, Shallop A, Jones RA. Syntheses of $\left[1,7-{ }^{15} \mathrm{~N}_{2}\right]-$ and $\left[1,7, \mathrm{NH}_{2}{ }^{-15} \mathrm{~N}_{3}\right]$ Adenosine and 2'-Deoxyadenosine via an Nl-Alkoxy-Mediated Dimroth Rearrangement. J Org Chem 1998;63:3213-3217.

27. Wang L, Hirayasu K, Ishizawa M, Kobayashi Y. Purification of genomic DNA from human whole blood by isopropanol-fractionation with concentrated Nal and SDS. Nucleic Acids Res 1994;22:1774-1775. [PubMed: 8202389]

28. Dennehy MK, Loeppky RN. Mass spectrometric methodology for the determination of glyoxaldeoxyguanosine and $O^{6}$-hydroxyethyldeoxyguanosine DNA adducts produced by nitrosamine bident carcinogens. Chem Res Toxicol 2005;18:556-565. [PubMed: 15777095]

29. Marsch GA, Mundkowski RG, Morris BJ, Manier ML, Hartman MK, Guengerich FP. Characterization of nucleoside and DNA adducts formed by S-(1-acetoxymethyl)glutathione and implications for dihalomethane-glutathione conjugates. Chem Res Toxicol 2001;14:600-608. [PubMed: 11368561]

30. Thomson NM, Mijal RS, Ziegel R, Fleischer NL, Pegg AE, Tretyakova N, Peterson LA. Development of a quantitative liquid chromatography/electrospray mass spectrometric assay for a mutagenic tobacco-specific nitrosamine-derived DNA adduct, $O^{6}$-[4-oxo-4-(3-pyridyl)butyl]-2'deoxyguanosine. Chem Res Toxicol 2004;17:1600-1606. [PubMed: 15606135]

31. Koc H, Swenberg JA. Applications of mass spectrometry for quantitation of DNA adducts. J Chromato B Analyt Technol Biomed Life Sci 2002;778:323-343.

32. McMurray, J. Organic Chemistry. Brooks/Cole Publishing Co; Pacific Grove, CA: 1996.

33. Jeong YC, Sangaiah R, Nakamura J, Pachkowski BR, Ranasinghe A, Gold A, Ball LM, Swenberg JA. Analysis of MIG-dR in DNA by aldehyde reactive probe labeling and liquid chromatography tandem mass spectrometry. Chem Res Toxicol 2005;18:51-60. [PubMed: 15651849]

34. DeMarini DM, Landi S, Ohe T, Shaughnessy DT, Franzen R, Richard AM. Mutation spectra in Salmonella of analogues of MX: implications of chemical structure for mutational mechanisms. Mutat Res 2000;453:51-65. [PubMed: 11006412]

35. Franzen R, Goto S, Tanabe K, Morita M. Genotoxic activity of chlorinated butenoic acids in Salmonella typhimurium strains TA98, TA100 and TA104. Mutat Res 1998;417:31-37. [PubMed: 9729256]

36. Chen B, Bohnert T, Zhou X, Dedon PC. 5'-(2-phosphoryl-1,4-dioxobutane) as a product of 5'oxidation of deoxyribose in DNA: elimination as trans-1,4-dioxo-2-butene and approaches to analysis. Chem Res Toxicol 2004;17:1406-1413. [PubMed: 15540938] 

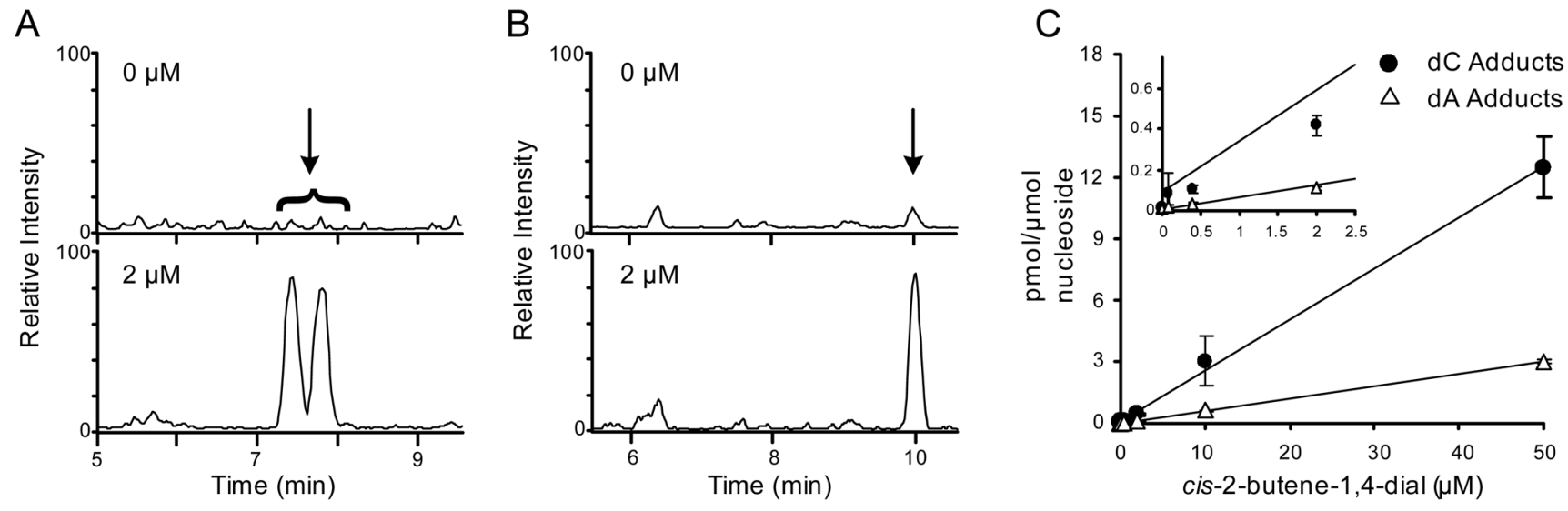

Figure 1.

Formation of DNA adducts in calf-thymus DNA treated with cis-2-butene-1,4-dial. A) Representative capillary LC-MS traces obtained when monitoring the $m / z, 417 \rightarrow 307$ low energy transition for the derivatized cis-2-butene-1,4-dial-dCyd adducts in enzyme hydrolysates of 0 or 2 ( $\mu \mathrm{M}$ cis-2-butene-1,4-dial-treated calf thymus DNA. B) Representative capillary LC-MS traces obtained when monitoring the $m / z \rightarrow 307$ low energy transition for the derivatized cis-2-butene-1,4-dial-dAdo adducts in enzyme hydrolysates of 0 or $2 \mu \mathrm{M} \mathrm{cw}-2$ butene-1,4-dial-treated calf thymus DNA. C) Graph demonstrating the linear relationship between the concentration of cis-2-butene-1,4-dial and the levels of the derivatized dCyd and dAdo adducts formed (dial $=\mathrm{cw}-2$-butene-1,4-dial). 

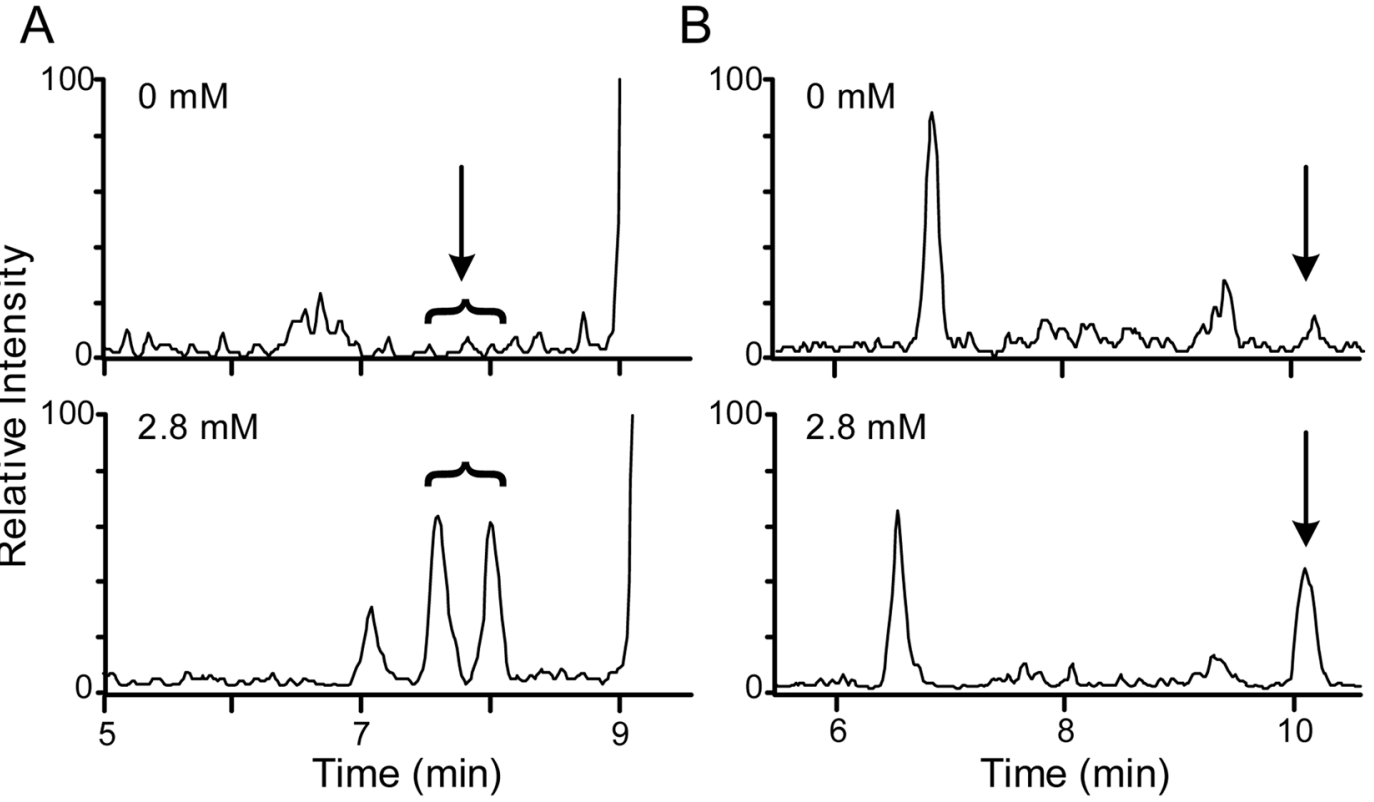

Figure 2.

Detection of DNA adducts in DNA isolated from $S$. typhimurium TA104 bacteria treated with 0 or $2.8 \mathrm{mM}$ cis-2-butene-1,4-dial for $30 \mathrm{~min}$. A) Representative capillary LC-MS traces obtained when monitoring the $m / z, 417 \rightarrow 176$ high energy transition of the derivatized cis-2butene-1,4-dial-dCyd adducts (6). B)Representative capillary LC-MS traces obtained when monitoring the $m / z, 423 \rightarrow 173$ high energy transition of the derivatized cis-2-butene-1,4-dialdAdo adducts (7) 


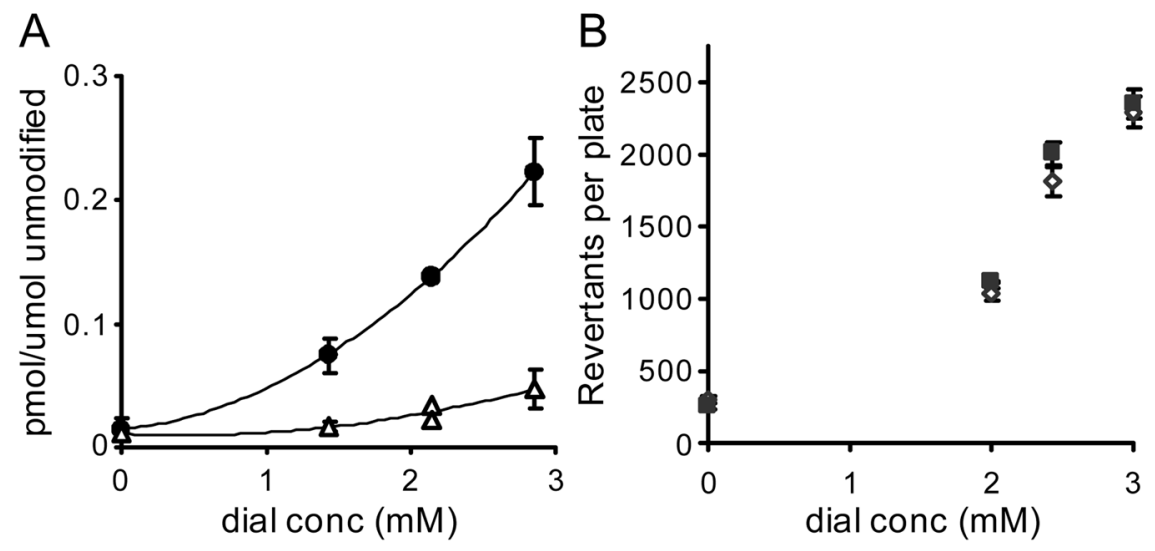

Figure 3.

Formation of DNA adducts in S. typhimurium TA104 bacteria treated with cis-2-butene-1,4dial. A) Relationship between the concentration of cis-2-butene-1,4-dial and the levels of the derivatized $\mathrm{dCyd}(\bullet)$ and dAdo $(\Delta)$ adducts formed in DNA isolated from treated TA104 bacteria $(n=3$, mean \pm SD; except 2.1 where $n=2)$. B) Relationship between the concentration of cis-2-butene-1,4-dial and the Ames assay reversion rate (modified from reference (11). The data points represent two different experiments (mean $\pm \mathrm{SD}, \mathrm{n}=4$ ). 


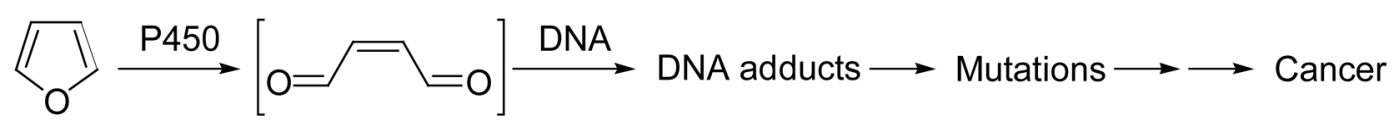

Scheme 1.

Potential genotoxic mechanism of furan-induced carcinogenesis. 

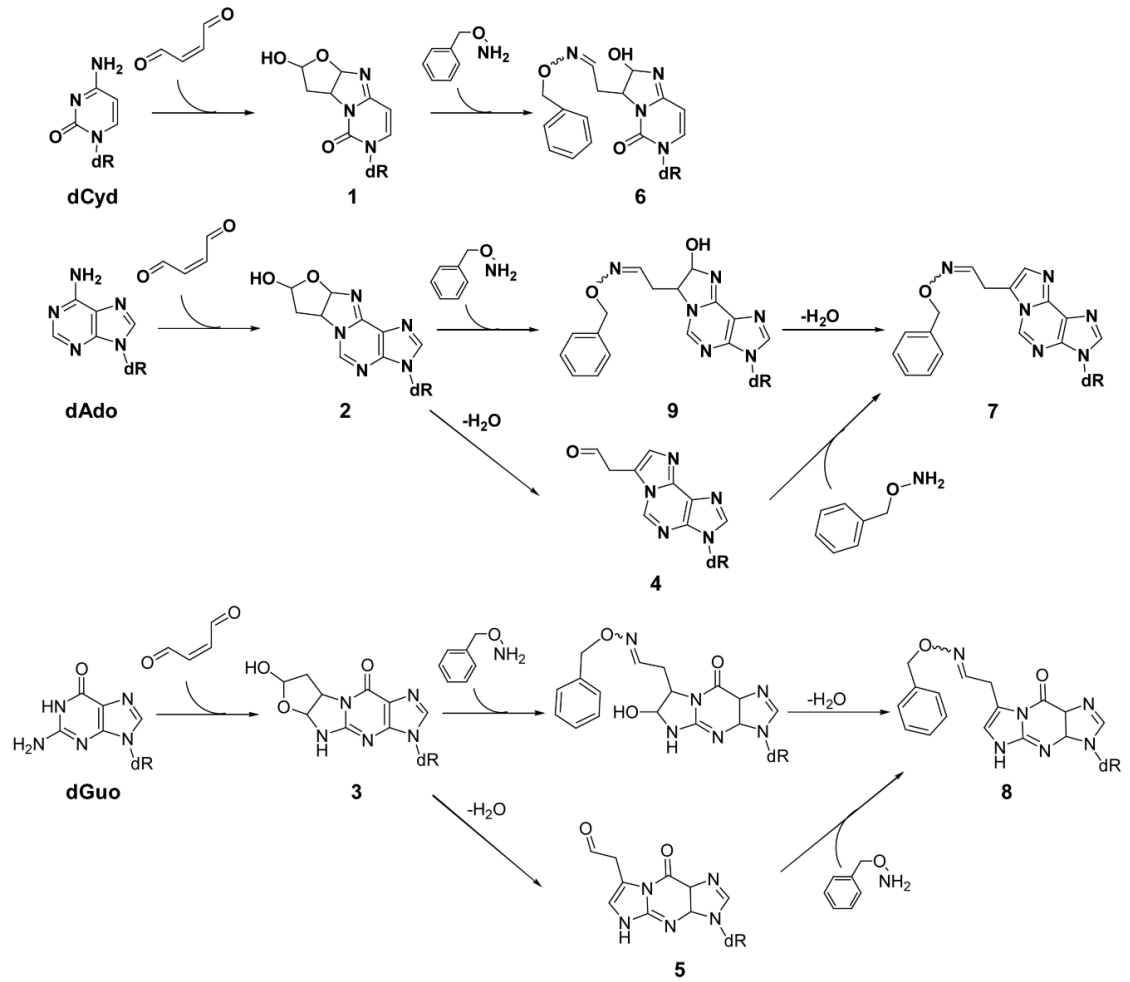

Scheme 2.

Formation of nucleoside adducts by $c i s$-2-butene-1,4-dial and derivatization with 0 benzylhydroxylamine. 


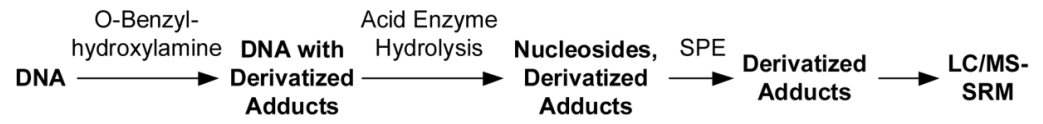

Scheme 3.

Overall strategy for the detection of cis-2-butene-1,4-dial-derived DNA adducts (SRM = selected reaction monitoring). 
A

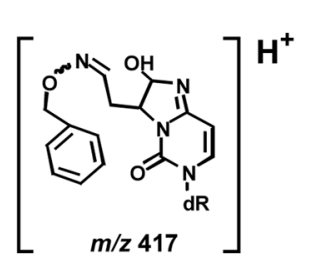

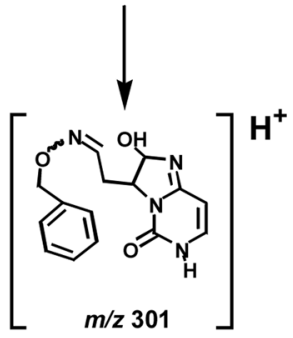

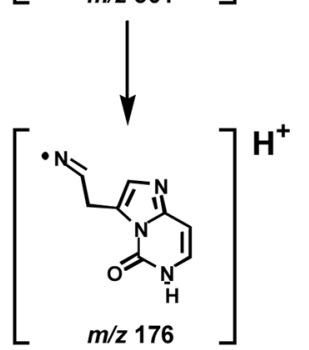

B

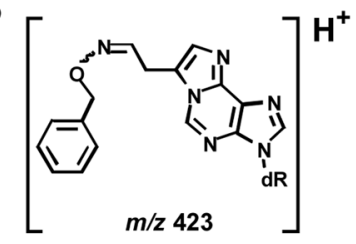

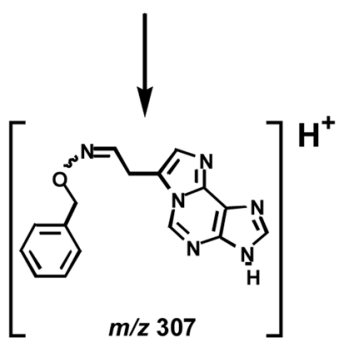

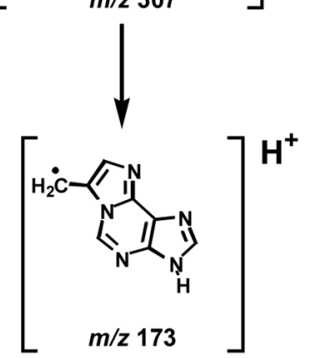

C

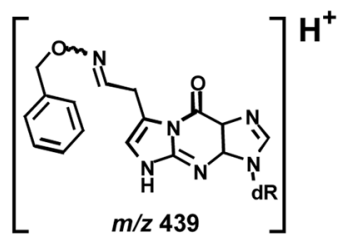

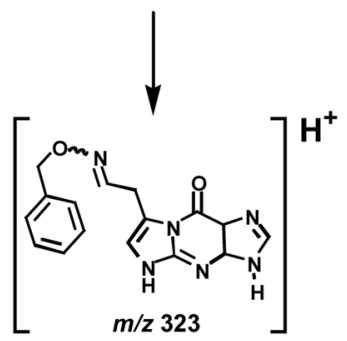

Scheme 4.

Fragmentation patterns observed by capillary LC/MS-SRM for the derivatized cis-2butene-1,4-dial adducts of (A) dCyd, (B) dAdo, and (C) dGuo. 